\title{
The Impact of Changes in Environmental Meanings on Users' Perceptions: A Case Study of Infill Architecture in the Historic Bazaar of Tabriz
}

Minou Gharehbaglou ${ }^{1}$ | Ilgar Ardabilchi ${ }^{2}$

Received: 2020-08-02 | Last version: 2021-01-08

\begin{abstract}
Infill architecture in historic contexts is a concept that requires careful examination in terms of visiting users perceptions and environmental meanings. This is of particular importance insofar as infill architecture can facilitate the preservation of physical and non-physical heritage in historic contexts because any interference in the historical context is closely related to environmental perceptions and meanings. In this respect, the Historic Bazaar of Tabriz, as a World Heritage site listed by the UNESCO World Heritage Center, requires special considerations. Accordingly, this study aims to investigate the status of the Historic Bazaar of Tabriz considering the changes brought about by the infill architecture. More particularly, it seeks to explore visiting users' perceptions of the infill architecture and observing changes in the environmental meanings of this Bazaar. Using a deductive method, the study has tried to identify whether and how changes in environmental meanings could affect visiting users' perceptions of the new buildings of a historic context. In this regard, tradespeople, customers, and residents in the intended context completed 350 closed-ended questionnaires. The findings show that changes in the physical and non-physical components of the historic context have altered the reactive and visual aspects of environmental meanings. Based on the obtained data, changes in the reactive, prescriptive, affective, and judgmental aspects of environmental meanings have affected visiting users' perceptions of the infill architecture at cognition, interpretation, and valuation levels. This reflects the impact of changes in environmental meanings in relation to functional, historical, cultural, and social factors on users' perceptions.
\end{abstract}

Keywords: Meaning; perception; infill architecture; historic context

Citation

Gharehbaglou, M. \& Ardabilchi, I. (2021). The Impact of Changes in Environmental Meanings on Users' Perceptions. A Case Study of Infill Architecture in the Historic Bazaar of Tabriz. ACE: Architecture, City and Environment, 16(47), 9638. DOl: http://dx.doi.org/10.5821/ace.16.47.9638

\section{El Impacto de las variaciones en los sentidos ambientales sobre la percepción del usuario: un estudio de caso sobre arquitectura de relleno en el bazar histórico de Tabriz}

Abstract

\begin{abstract}
La arquitectura de relleno en contextos históricos es un concepto que requiere un examen cuidadoso en términos de las percepciones de los usuarios visitantes y los sentidos ambientales. Esto es de particular importancia en la medida en que la arquitectura de relleno puede facilitar la preservación del patrimonio físico y no físico en contextos históricos porque cualquier interferencia en el contexto histórico está estrechamente relacionada con las percepciones. En este sentido, el Bazar Histórico de Tabriz, como Patrimonio de la Humanidad inscrito por la UNESCO, requiere consideraciones especiales. Este estudio investiga el estado del Bazar Histórico de Tabriz a la luz de los cambios provocados por la arquitectura de relleno. Particularmente, explora las percepciones de los usuarios visitantes sobre la arquitectura de relleno y observar los cambios en los sentidos ambientales del Bazar. Utilizando un método deductivo, el estudio identifica si los cambios en los sentidos ambientales pueden afectar las percepciones de los usuarios visitantes de los nuevos edificios de un contexto histórico y cómo lo hacen. En este sentido, comerciantes, clientes y residentes completaron 350 cuestionarios. Los hallazgos muestran que los cambios en los componentes físicos y no físicos del contexto histórico han alterado los aspectos reactivos y visuales de los sentidos ambientales. Además, los cambios en los aspectos reactivos, prescriptivos, afectivos y de juicio de los sentidos ambientales han afectado las percepciones de los usuarios visitantes de la arquitectura de relleno en los niveles de cognición, interpretación y valoración. Esto refleja el impacto de las variaciones en los sentidos ambientales en relación con factores funcionales, históricos, culturales y sociales en las percepciones de los usuarios.
\end{abstract}

Palabras clave: Sentido, percepción; arquitectura de relleno; contexto histórico

${ }^{1}$ Associate Professor, Faculty of Architecture and Urbanism, Tabriz Islamic Art University (ORCiD: 0000-0003-2639-

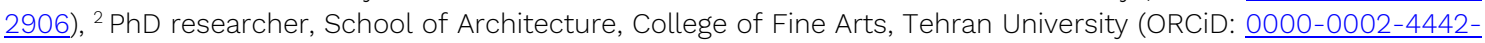
7175), Contact e-mail: m.gharehbaglou@tabriziau.ac.ir 


\section{Introduction}

The addition of new structures to a historic context is not a new phenomenon, it was first proposed for the first time in the 20th century as a method for efficient urban development with emphasis on the maximum use of available facilities available within urban contexts (Gharebaglou et al., 2019).

Accordingly, paying attention to changes, occurring due to the added structures, as well as to the perception and meaning of the historical context is of significance since an aspect of the importance of a historical context, which should permanently be considered in the intended studies, is the data that are represented in individuals in various physical and non-physical dimensions through understanding the perceptions and meanings attributed to them. Despite the significance of this issue, studies on the infill architecture in the historical context, to the best of our knowledge, have focused on the process of design approaches (e.g., Naghavi and Mazaherian, 2019; Soosani, 2013; Navickiene, 2012; Sotoudeh and Wan Abdullah, 2013; Heritage Office, 2011).

However, from this perspective, attention to the perception and meaning is ignored despite its importance, and this research gap, in turn, is one of the factors that can lead to the failure of the selected and presented design approach from the researchers' viewpoint. This is observable in some infill buildings in the Historical Bazaar of Tabriz. To address this gap and the perception and meaning in studies related to the infill architecture in the historical context, the present study aimed the present study aims to explore the visiting users' perceptions and possible changes in environmental meanings because of the infill architecture to obtain at workable measures. so that avoid the effects of adding new structures to the historical context as much as possible and to enjoy its potentials as far as possible, especially the case study.

Regarding the proposed mechanism, which is based on theoretical foundations, the present study evaluated the effect of changes in environmental meanings because of the infill architecture in the historical context on users' perceptions.

In this respect, for understanding some issues, the following questions can help us define a framework for the study: How and to what extent did infill-caused changes in environmental meanings affect the users' perceptions? And, to what extent? In the following's sections, we will explore the proposed mechanism and its mode of operation are evaluated using via a deductive method. According to Blaikie (2010), "this deductive research strategy begins with an already discovered and established pattern or regularity that has already discovered and stablished, and which begs an explanation. The task seeks to test that theory by deducting one or more hypotheses from it and then to collect appropriate data in this regard" (2010, pp. 8-9). It should be noted that this method is mainly applied in architectural and urban studies in the field of semiotics. In the present study, it is attempted to use a different knowledge area, namely, linguistic approach to explore environmental semantics.

In this approach, semantic theories are defined as the studying of the meanings and methods of signification in a psychological context. By reconciling semantics with perception processes via a psychological perspective to architecture and urban environments, it is we sought aim to formulate a mechanism by which the users can make sense of a given environment. To this end, in the current study we have used Ittelson's perceptual theory. In accordance with our linguistic approach to explore environmental semantics, users' perceptions are best quantified through self-reported surveys.

ACE, 16 (4.7) CC BY-ND 3.0 ES | UPC Barcelona, España | The Impact of Changes in Environmental Meanings on

Users' Perceptions. DOI: http://dx.doi.org/10.5821/ace.16.47.9638 


\section{Review of Literature}

Semantics are studied through different approaches. For example, Kellerhals et al., (2007) studied environmental semantics using a phenomenological paradigm based on users' descriptions of space. They recoded the participants' perceptions of two libraries in different locations with different physical attributes. The findings showed that the overall features of a building, including those around the building (e.g., location, legends, and media reports), and the ones belonging to the building itself (e.g., typology, and architecture), inside the building (e.g., furniture, arrangement, color, and materials), and on the building (e.g., signaletics) are conceived as the codes or signs that help a perceiver interpret the environmental meanings surrounding that building.

According to Taurens (2008), such codes in the architecture compose a language system that should be studied in terms of semantics. To find the answer to the question of 'how does architecture becomes meaningful? He draws on inter- and intra-linguistic concepts and comes up with two general approaches namely, classical semantics and applied semantics. Although whereas the former helps us make sense of architecture as a concept based on similar rules, the latter is based on the context that accommodates a given building. The existence of many semantic components in the environment sometimes directs researchers toward limiting their studies to a specific component.

Zhang and Kang (2010) investigated environment-related meanings as derived from sound-codes in open urban spaces. Using a semantic differential grid, they posited that person-specific data, especially age and a specialty in designing, could be very effective in shaping the meanings attributed to a given environment. Furthermore, Marotta et al., (2017), by applying semantic theories to the language of architecture as a visual system, stated that the signifier may interact with positive and negative indices, thus, providing an appropriate basis for analyzing meanings in visual and architectural works.

A brief literature review indicates that previous studies have focused on codes that rely on objective categories, such as sound and physical characteristics, and serve as the basis for environmental meanings and perceptions. Although such an approach provides trustworthy data through the direct observations of concrete reality, it fails to consider conceptual dimensions that affect meanings and perceptions, such as cultural and value issues. Therefore, it is therefore necessary to consider all effective dimensions for a holistic approach. Accordingly, this study focuses on physical and nonphysical dimensions to cover the issue in terms of the effect of the infill architecture on changes in environmental meanings and the user's perceptions of the historical context within the scope of physical and non-physical heritage. Thus, it is necessary to examine the intended research definition of the two terms of perception and meaning, especially in the intended approach.

\section{Perception and Meaning of the Environment}

In this study, a linguistic approach was adopted relying on the assumption that language is the most important means for communicating on and of making sense of the surrounding world and that are similarities between the communicative language and systems of architecture/urbanism, we have adopted a linguistic approach in this study. From the author's perspective, although semantic theories are presented under linguistics, they are themselves somehow based on psychology since they examine the meaning and method of linguistic formation with respect to the function of the mind since psychology can be defined as the science of studying the function of the mind. Therefore, important psychological theories received special attention in the study of the process of perceptions.

ACE, 16 (47) CC BY-ND 3.0 ES | UPC Barcelona, España | The Impact of Changes in Environmental Meanings on

Users' Perceptions. DOI: http://dx.doi.org/10.5821/ace.16.47.9638 
Our perceptions of the surrounding environment constitute a subjective-objective process through which environmental stimuli are rendered by our senses to our nervous systems and then identified and organized by the brain (Nagar, 2006). Accordingly, as a result, reactive processes are formed in the human mind in response to environmental stimuli (Cassidy, 2013). Based on this definition, the most recent approach in perceptual studies, namely that, the school of interaction, lays the basis for Ittelson's interactive/reciprocal model of perception (1960). Also, according to this theory, there is a dynamic relationship between the environment and a human being, and the environment is a dynamic one in which the perceiver must play an active role (Lang, 1987). In other words, a variety of factors are involved in this active perceptual process, including such as individual characteristics (i.e., age, and gender), psychology (i.e., introversion or extroversion), natural and intrinsic factors, and the social, cultural, and economic context in which an individual grows up.

The three most extensively applied perceptual theories in this school are those presented by Itelson (1978), Epiliard (1970), and Carmona (2003). According to the authors, these three theories have overlapping aspects and are compatible. Nonetheless, in Epiliard's theory compared to Itelson 's, and in Carmona's theory in comparison to that of Itelson, an aggregation and distinctions have respectively been made that are more than the objectives of this research regarding consistency with semantic theories. Thus, Itelson's theory was considered as the basis of this study.

According to Ittelson (1978), an individual's perception of the surrounding environment and of external stimuli can be examined at four levels: cognitive, affective, interpretive, and evaluative. At the cognitive level, the environment is considered as an external entity independent of the perceiving individual and his/her experience, which is to be perceived, analyzed, interpreted, organized, stored, and made sense of. At this level of perception, the emphasis is placed on the cultural, social, and physical aspects of the environment. At the affective level, the environment is recognized as part of the perceiver's identity. This view recognizes the mutual relationship between the perceiver and the environment. In this sense, as part of the perceiver's identity, the environment is believed to affect and be affected by the perceiver's feelings.

However, at the interpretive level, the environment is, in functional terms, considered to be a site or backdrop for the occurrence of activities. For some perceivers, this dimension is the key to spatial perception such that their descriptions and interpretations of the environment are entirely focused on the use of space. At the level of valuation, the perceiver's values and preferences are prioritized at the level of valuation. Moreover, this level, the environment is treated as a source or the embodiment of important feelings and values at this level. For many individuals, a city is like an environment with a system of potentially visualizable values. Therefore, ethical, spiritual, religious, spiritual, ethical, and aesthetic values are involved in this dimension of perception (Ittelson, 1996; Altman and Christensen, 2012; Del Nord, 2009; Stokol, 2013). These four levels of perception simultaneously interact with the environment simultaneously and rely on both environmental and individual characteristics (Table 1).

In this sense, meaning in semantics is a referent that exists in the external world or a concept that is created as a schema in language speakers' minds (Geeraerts, 2010). In summary, the theories of meaning formation define meaning by recourse to conceptual relations (Mental schemata) or structural rules (The syntax). From among the theories of meaning formation that have so far been proposed, those that can be generalized to the fields of architecture and urbanism are as follows:

ACE, 16 (4.7) CC BY-ND 3.0 ES | UPC Barcelona, España | The Impact of Changes in Environmental Meanings on

Users' Perceptions. DOI: http://dx.doi.org/10.5821/ace.16.47.9638 
- Referential/denotational semantics: According to this theory, the meaning is something which is referred to (Lyons, 1977; Kempson, 1977; Cann, 1993). This referent of meaning formation can take the form of a tangible physical object, an action, or thought or some abstract quality concepts.

- Behavioral/psychological semantics: This theory defines the meaning of a stimulus as the perceiver's visible and recordable response to that stimulus (Mokhtar Omar, 2007). Based on this theory, at least part of the meaning of an environment can be inferred from a user's observable behavior and how he/she applies the space (Kempson, 1977; Cann, 1993).

- Ideational/mentalistic semantics: According to this theory, the meaning of a word/phrase is the concept that exists in the minds of those who are familiar with it (Lyons, 1995). In this sense, the meaning is considered a subjective quality in the mind of the knowing subject, which is independent of any external referent and behaviors or perceptions for that matter (Geeraerts, 2010).

- Functional/applied semantics: Based on this theory, the meaning of a word/phrase is identified by its usage (Lyons, 1995) alongside other units of linguistic or non-linguistic meaning (Safavi, 2011; Cann, 1993).

Table 1. Dimensions of Environmental Perception and the Related Affecting Factors

\begin{tabular}{|l|l|}
\hline Level of Perception & Definition \\
\hline Cognitive & $\begin{array}{l}\text { Analyzing and interpreting environmental stimuli as external phenomena } \\
\text { independent of the perceiver in a cultural, social, and physical context, as well as } \\
\text { organizing and storing them to evaluate the environment }\end{array}$ \\
\hline Affective & $\begin{array}{l}\text { The reciprocal impact of the perceiver's perceptions on the environment as part } \\
\text { of his/her identity and the environment on the perceiver's feelings via mood and } \\
\text { affect }\end{array}$ \\
\hline Interpretive & $\begin{array}{l}\text { The perceiver's attention to the context of usage and environmental activities } \\
\text { ethical, spiritual, religious, and aesthetic values }\end{array}$ \\
\hline Evaluative \\
Source. Prepared by the authors. \\
Note. Data were adapted from Ittelson (1978) and Ittelson, Frank, and O'Hanlon (1976).
\end{tabular}

\subsection{Environmental Semantics as an Approach to Environmental Perception}

Meaning formation occurs as an extension of the perception process. For the perceiver's mind to make sense of the environment, input data and stimuli are derived from two sources including the stored data in the perceiver's memory as the result of past experiences and new environmental stimuli, whose output is influenced by the perceiver's experiences of the environment, and thus affecting his/her mental images and behavior. Accordingly, meaning formation is the processes by which environmental meanings, namely, the characteristics, features, and states of a given environment take the form of concepts for the perceiver.

In this study, the first source, (i.e., environmental stimuli) is considered based on semantic theories. Thus, their intended concepts were generalized to the literature of architecture and urban planning (Table 1). Based on this diagram, Environmental meanings refer to forms (physical-environmental components), activities (functional components), or the perceiver's mental images of the environment (i.e., historical, cultural, and social components), the details of which are provided in Table 2.

Hershberger (1974) categorized these concepts into imaginative and reactive levels. At the imaginative level, environmental meanings are the result of recognizing environmental components and making sense of the signs and symbols. To put it differently, at this level of meaning formation, the meaning is equivalent to one's perception of the environment. It follows that meaning is either immediate or non-discursive and occurs after the observation (expository meaning) or it is the result of a more

ACE, 16 (4.7) CC BY-ND 3.0 ES | UPC Barcelona, España | The Impact of Changes in Environmental Meanings on

Users' Perceptions. DOI: http://dx.doi.org/10.5821/ace.16.47.9638 
profound understanding (referential meaning). At the responsive/reactive level, however, environmental meanings, according to Nasar (1990), can result from different sources such as the perceiver's emotions and feelings (affective meaning), the desirability of environmental evaluations (judgmental meaning), or environmental reinforcements for the perceiver to exhibit a certain behavior (prescriptive meaning). A single index or a combination of indices can result from the environment while applying a semantic theory to these notions of environmental meaning (Figure 1).

Table 2. Semantic Theories Compared to Environmental Indicators and Meanings in Architecture

\begin{tabular}{|c|c|c|c|c|c|}
\hline \multirow[t]{2}{*}{$\begin{array}{l}\text { Semantic } \\
\text { Theory }\end{array}$} & \multirow[t]{2}{*}{$\begin{array}{l}\text { Definition of Theory } \\
\text { in Linguistics }\end{array}$} & \multirow[t]{2}{*}{ Methodology } & \multicolumn{2}{|c|}{$\begin{array}{l}\text { Comparison of Semantic Theories } \\
\text { and Architecture }\end{array}$} & \multirow[t]{2}{*}{ Reference } \\
\hline & & & $\begin{array}{l}\text { Effective } \\
\text { Spatial } \\
\text { Attributes }\end{array}$ & $\begin{array}{l}\text { Architecture- } \\
\text { Compatible Definition }\end{array}$ & \\
\hline Behavioral & $\begin{array}{l}\text { The meaning of a } \\
\text { word or phrase } \\
\text { depends on the } \\
\text { perceiver's response } \\
\text { or reaction to that } \\
\text { meaning. }\end{array}$ & $\begin{array}{l}\text { such as library } \\
\text { reading, } \\
\text { snapshots, and } \\
\text { observations }\end{array}$ & Activities & $\begin{array}{l}\text { Environmental } \\
\text { meanings arise from } \\
\text { user behaviors and } \\
\text { actual activities. }\end{array}$ & $\begin{array}{l}\text { Mokhtar } \\
\text { Omar, 2007; } \\
\text { Kempson, } \\
\text { 1977; Cann, } \\
1993\end{array}$ \\
\hline $\begin{array}{l}\text { Conceptu } \\
\text { al }\end{array}$ & $\begin{array}{l}\text { The meaning of a } \\
\text { word or phrase arises } \\
\text { from its concept in } \\
\text { the mind of the } \\
\text { perceiver (Mokhtar } \\
\text { Omar, 2007; Lyons, } \\
\text { 1995). }\end{array}$ & $\begin{array}{l}\text { such as library } \\
\text { reading, } \\
\text { interviews, } \\
\text { questionnaires. }\end{array}$ & $\begin{array}{l}\text { Mental } \\
\text { images }\end{array}$ & $\begin{array}{l}\text { Environmental } \\
\text { meanings arise from } \\
\text { concepts or mental } \\
\text { images that are } \\
\text { independent of } \\
\text { external referents } \\
\text { due to perceptual } \\
\text { processes. }\end{array}$ & $\begin{array}{l}\text { Lyons, 1995; } \\
\text { Lappin and } \\
\text { Fox, 2015; } \\
\text { Ogden et al., } \\
2013 .\end{array}$ \\
\hline Functional & $\begin{array}{l}\text { The meaning of a } \\
\text { word or phrase stems } \\
\text { from its function in } \\
\text { linguistic and non- } \\
\text { linguistic contexts } \\
\text { (Safavi, 2011; Mokhtar } \\
\text { Omar, 2007; Lyons, } \\
\text { 1997). }\end{array}$ & $\begin{array}{l}\text { Such as library } \\
\text { reading, } \\
\text { interviews, } \\
\text { questionnaires, } \\
\text { snapshots, and } \\
\text { observations. }\end{array}$ & $\begin{array}{l}\text { Mental } \\
\text { images, } \\
\text { forms, } \\
\text { and } \\
\text { activities }\end{array}$ & $\begin{array}{l}\text { Environmental } \\
\text { meanings arise from } \\
\text { cultural, economic, } \\
\text { social, affective, } \\
\text { temporal, and spatial } \\
\text { systems. }\end{array}$ & $\begin{array}{l}\text { Lyons, 1995; } \\
\text { Mokhtar } \\
\text { Omar, 2007; } \\
\text { Kempson, } \\
\text { 1999. }\end{array}$ \\
\hline
\end{tabular}

Source. Prepared by the authors.

Figure 1. Semantic Theories Compared to Hershberger's Four Levels of Meaning

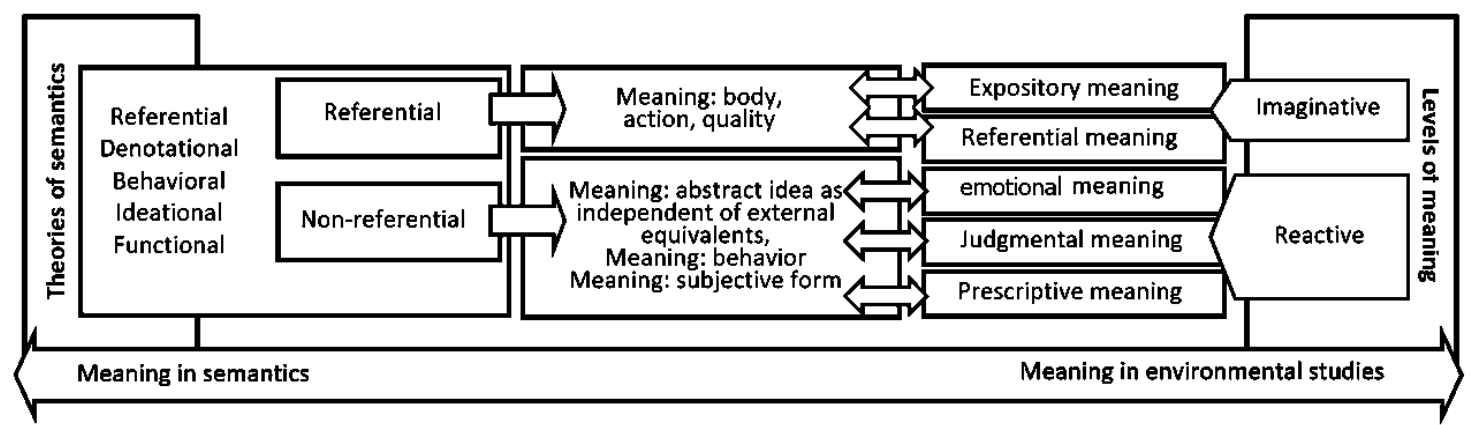

Source. Prepared by the authors.

Considering that the present study deals with the infill architecture in a historic context, Figure 2 captures the perceptual-semantic processes involved in the environmental perception and meaning formation considering the components of this type of infill architecture.

ACE, 16 (4.7) CC BY-ND 3.0 ES | UPC Barcelona, España | The Impact of Changes in Environmental Meanings on 
Figure 2. A Perceptual-semantic Model of the Infill Architecture in Historic Contexts

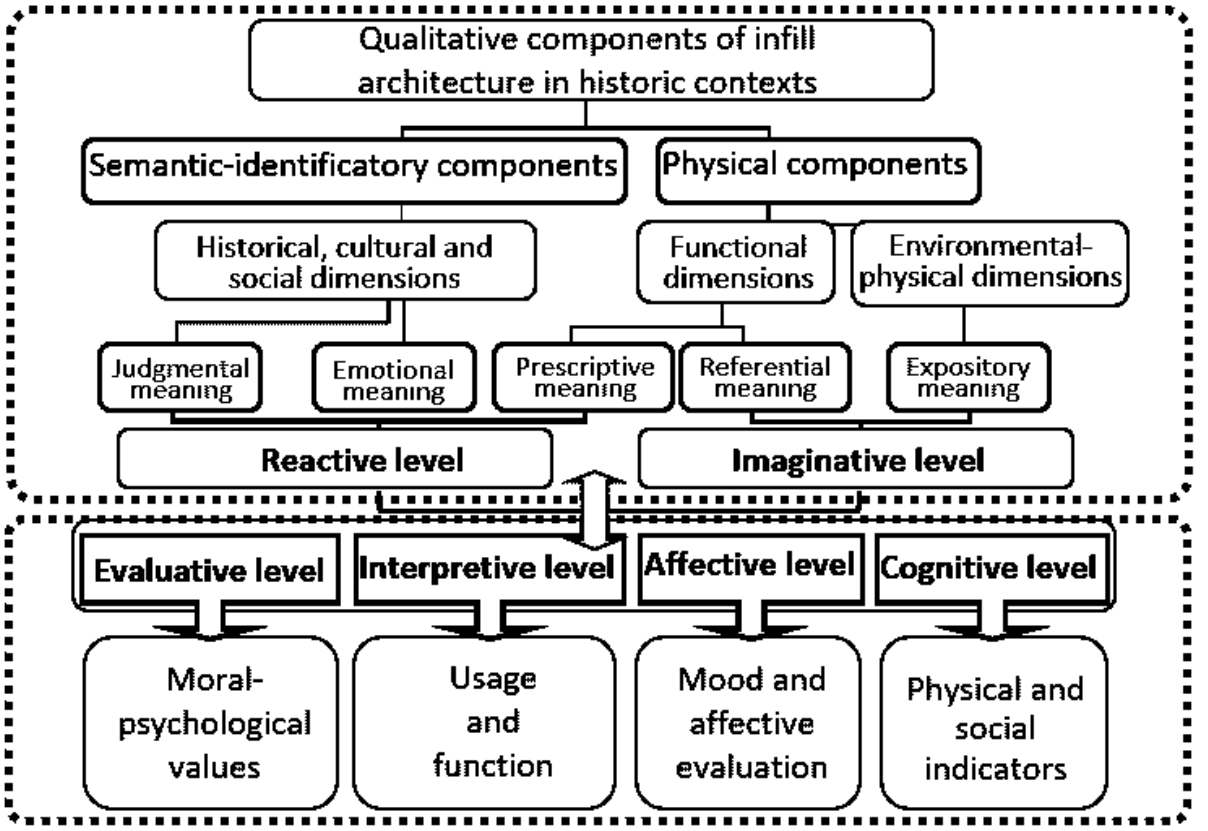

Source. Prepared by the authors.

\section{Methods and Procedures}

\subsection{Cases}

The Historic Bazaar Context of Tabriz has been one of the main trading platforms on the Silk Road since the middle of the $6^{\text {th }}$ century (Figs. 3, 4 and 5). It also features one of the largest roofed complexes in the world and is known to have played a formative role in the early development of this city. With its special structures for commercial, religious, educational, and healthcare purposes, it is one of the most influential historic contexts in Iran (Figure 6) and has been listed as a World Heritage site by UNESCO since 2010. From among the new structures added to the Historic Bazaar Context of Tabriz, Mashruteh and Saheb-ol-Amr Complexes have been selected as our case studies for their impact and vastness (Figure 7).

The map evaluations of this historical context show that Mashruteh Commercial Complex is built on the empty land resulting from the demolition of houses on the outskirts of the market and thus is in the spatial continuity of the market. Some of the structural and physical features of this building have been probably considered about the architecture of the market. For example, one of the applied materials in the facade of the building is brick, which creates a sense of connection between the two buildings in the eyes of the observer, and the linear pattern and grids of its spatial structure are partly reminiscent of the market space (Figure 8). On the other hand, Mashruteh Complex has also brought about changes in the context. The most important of these alterations are the creation of wider traffic routes (circulation) that allow the passage of trucks, buyers, and passive defense in emergencies, which was previously impossible due to the structure of the market. Further, the historical market was unable to increase the area of shops that facilitate offering and selling larger products (e.g., home appliances). 


\section{ACE Architecture, City and Environment}

E-ISSN1886-4805

The eastern wall of Mashruteh Complex is contiguous with the Historic Bazaar of Tabriz in terms of both physical and functional aspects (Figure 9). Saheb-ol-Amr Complex is also adjacent to the Historic Bazaar Complex and is located at the Saheb Abad Square, which is one of the most important historic squares of the city (Figure 10). The Saheb Abad Square was used to be an urban space that served a governmental purpose for the Aq-Qoyunlu Dynasty and was further expanded by the Safavid Dynasty (Chardin, 1677).

Although this complex with two streets and Mehranrood River, is physically separate from Tabriz Bazaar although the Bazar bridge has somehow established the spatial connection between these two sections. From the authors' viewpoint, this complex has paid more attention to the design of the historical market in terms of the structure and spatial pattern. The building is entirely made of brick and its linear and lattice pattern is more like the market pattern. In addition, the shortcomings of the historical context are considered in designing the complex, and as mentioned in Mashruteh Complex, strategies were proposed for them.

Figure 3. The Silk Roads from 13 AD to the beginning of $16 \mathrm{AD}$ and the Historic Bazaar of Tabriz

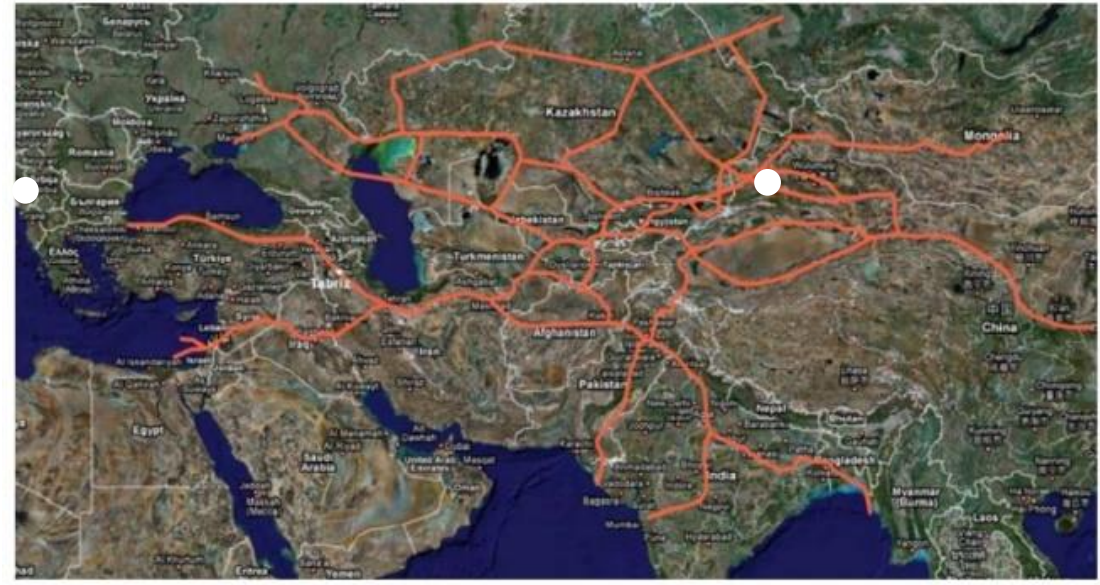

Source. Iranian Cultural Heritage, Handicrafts and Tourism Organization, 2009.

Figure 4. General View of the Historic Bazaar of Tabriz

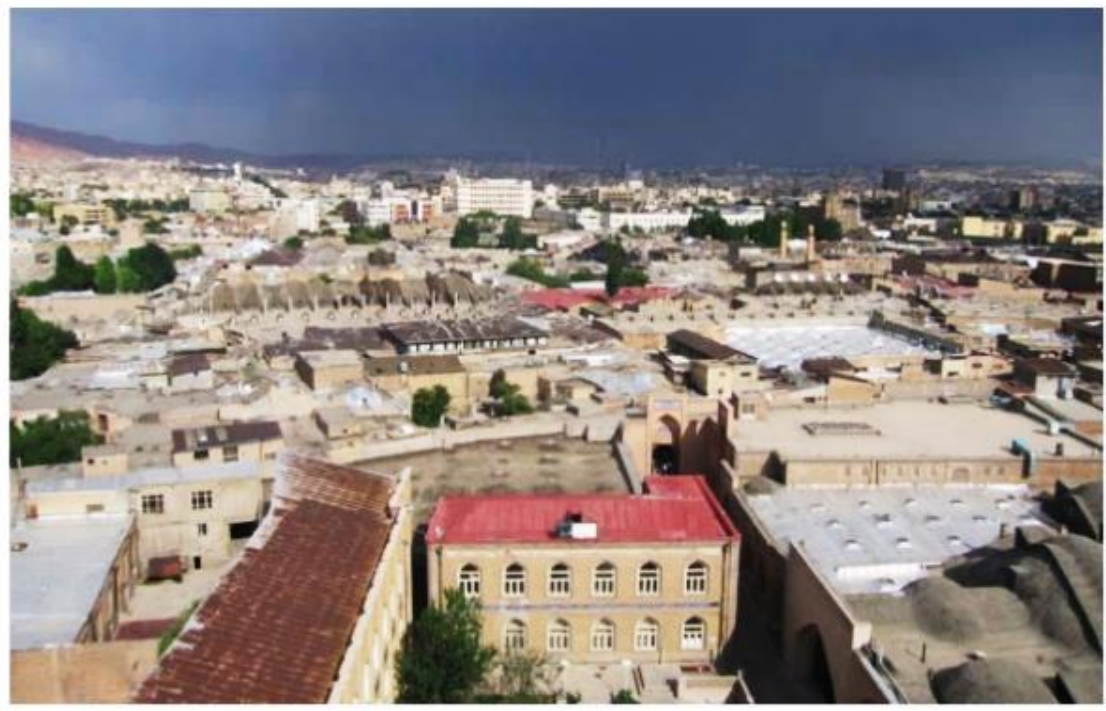

Source. Iranian Cultural Heritage, Handicrafts and Tourism Organization, 2009.

ACE, 16 (4.7) CC BY-ND 3.0 ES | UPC Barcelona, España | The Impact of Changes in Environmental Meanings on

Users' Perceptions. DOI: http://dx.doi.org/10.5821/ace.16.47.9638 
Figure 5. interior View of the Historic Bazaar of Tabriz

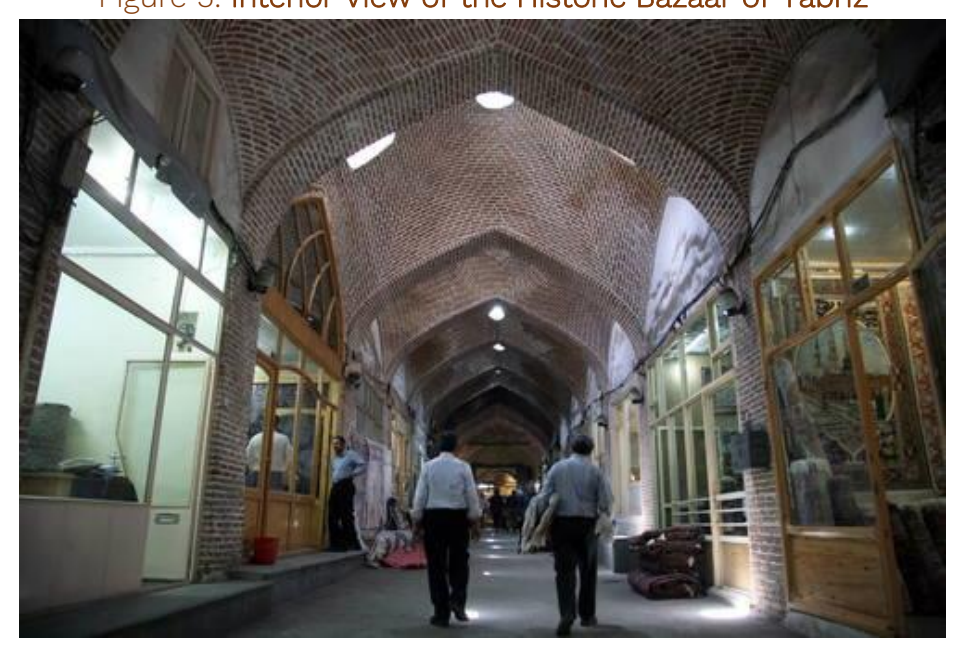

Source. Iranian Cultural Heritage, Handicrafts and Tourism Organization, 2009.

Figure 6. Major Functions of the Historic Bazaar of Tabriz

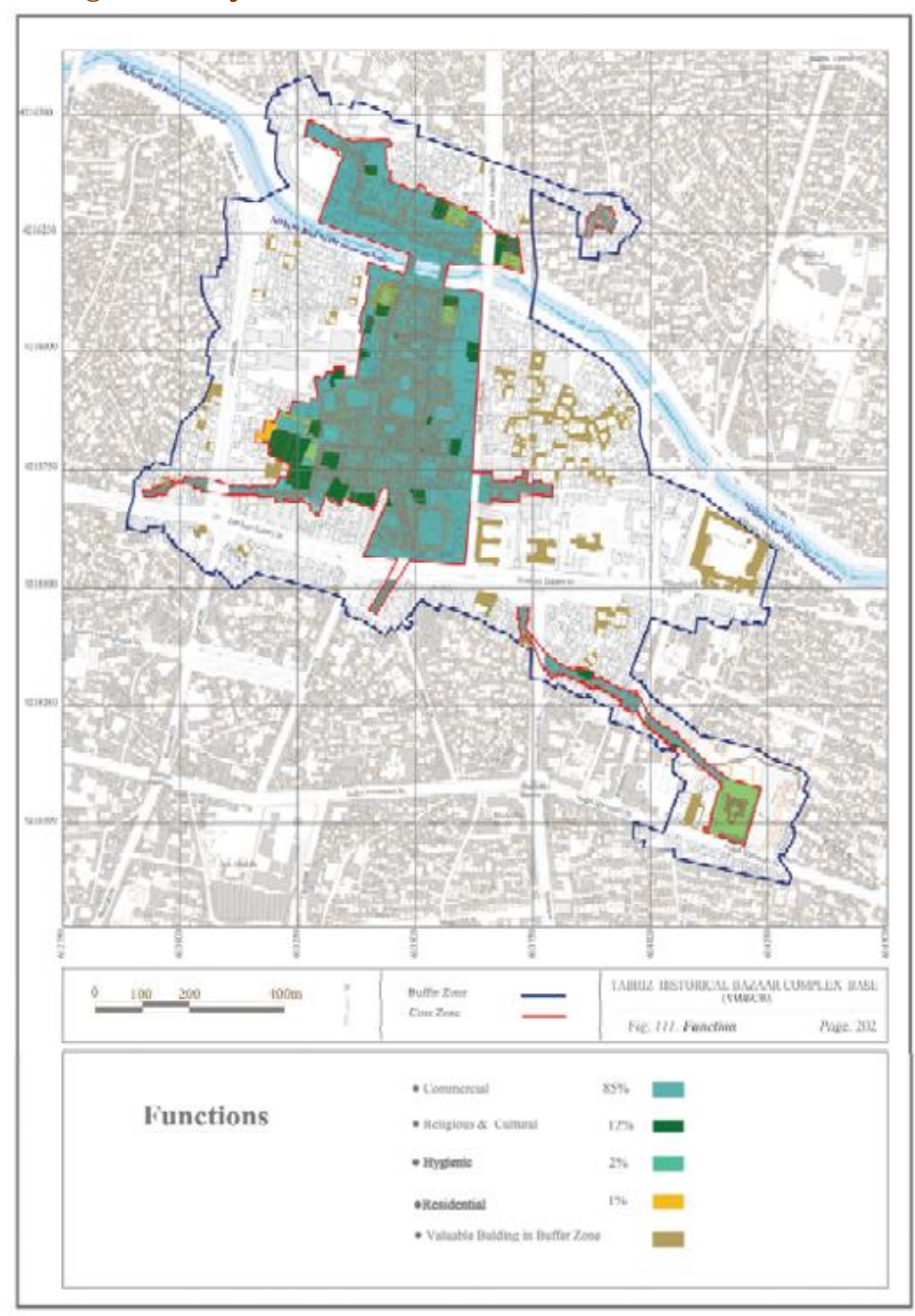

Source. Iranian Cultural Heritage, Handicrafts and Tourism Organization, 2009.

ACE, 16 (47) CC BY-ND 3.0 ES | UPC Barcelona, España | The Impact of Changes in Environmental Meanings on

Users' Perceptions. DOI: http://dx.doi.org/10.5821/ace.16.47.9638 


\section{ACE Architecture, City and Environment}

E-ISSN1886-480,

Figure 7. The Location of Mashruteh and Sāhib-ol-Amr Complex in the Historic Bazaar Context of Tabriz
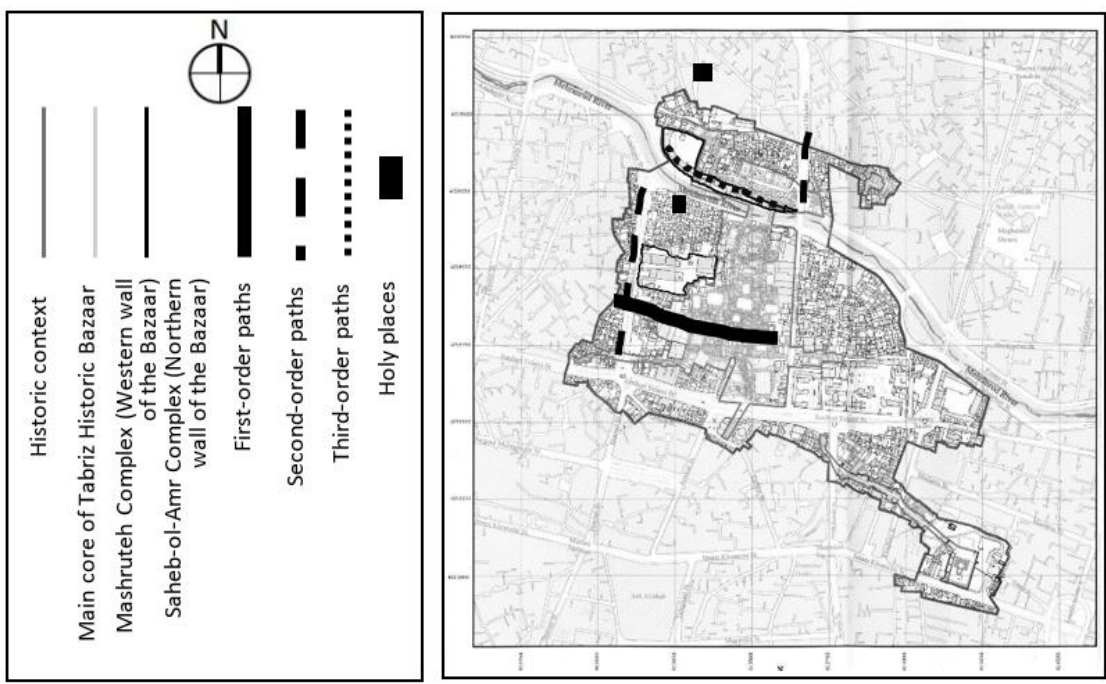

Source. Www.whc.unesco.org

Figure 8. Mashroteh Complex in the Historic Bazaar of Tabriz

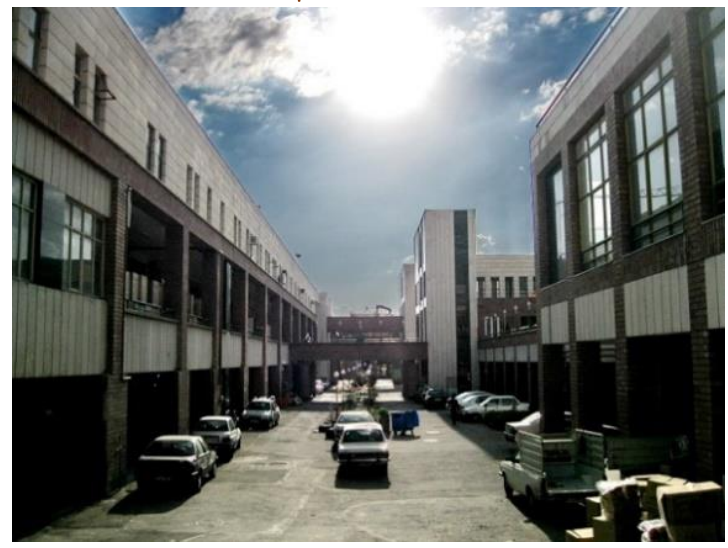

Source. Auteurs (2018).

Figure 9. Sāhib-ol-Amr Complex in the Historic Bazaar of Tabriz

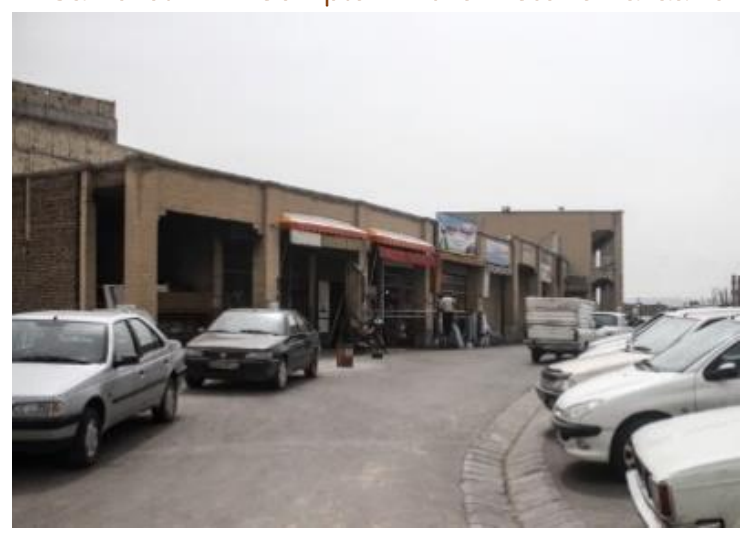

Source. Auteurs (2018)

ACE, 16 (47) CC BY-ND 3.0 ES | UPC Barcelona, España | The Impact of Changes in Environmental Meanings on 


\section{ACE Architecture, City and Environment}

Figure 10. Sāhib-ol-Amr Square before 1827 AD

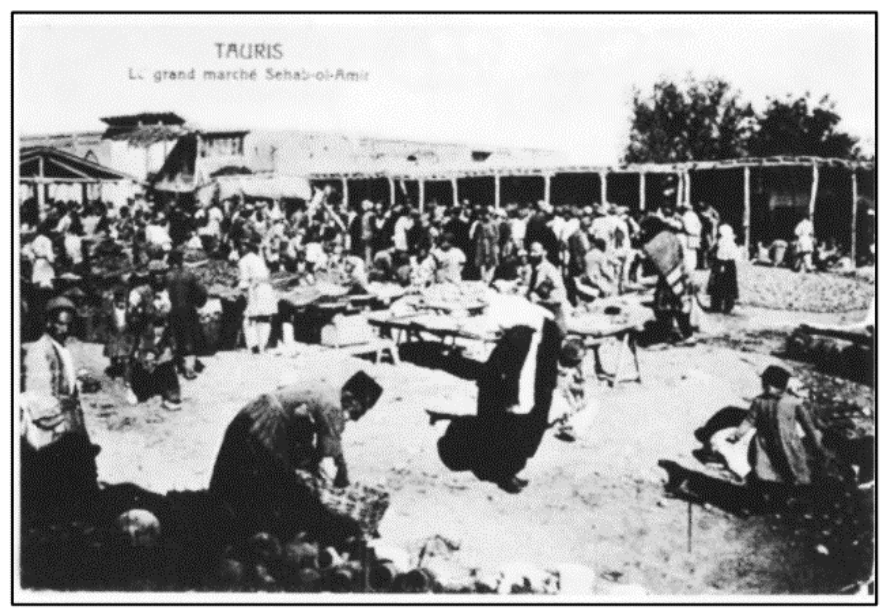

Source. Iranian Cultural Heritage, Handicrafts and Tourism Organization (2009).

\subsection{Statistical Population}

Based on the questions and objectives, the statistical population includes all visiting users with a perception of the historic context and the associated environmental meanings before the construction of Mashruteh and Saheb-ol-Amr Complexes. The population consists of three strata, namely, business owners and employees who work in the Historic Bazaar or the two trading complexes, those residing or working in the residential areas surrounding the Bazaar, and customers visiting the Historic Bazaar or Mashruteh and Saheb-ol-Amr Complexes. Out of this population, the participants were selected through a simple random sampling technique. Finally, 350 respondents completed and returned the questionnaires.

The number of these participants was determined by analyzing the questionnaires of the pre-test section (pilot) and the variance of the statistical analysis of their answers. However, it was necessary to limit the number of questionnaires during data collection. A sample size was dictated by limited access to the population and a minimum required number of respondents considering the number of neighborhoods in the historic context (Table 3).

Tabla 3. Demographics of Users' Visiting Mashruteh and Saheb-ol-Amr Complexes

\begin{tabular}{|c|c|c|c|c|c|c|c|c|c|c|c|c|c|c|c|c|}
\hline \multirow[t]{2}{*}{ Demographics } & \multicolumn{2}{|c|}{ Gender } & \multicolumn{4}{|c|}{ Age } & \multicolumn{4}{|c|}{ Education } & \multicolumn{4}{|c|}{ Purpose of Visit } & \multicolumn{2}{|c|}{$\begin{array}{l}\text { Frequency } \\
\text { of Visit }\end{array}$} \\
\hline & ४ & $\Sigma$ & 旁 & $\begin{array}{l}\text { f } \\
\dot{y} \\
\text { f }\end{array}$ & 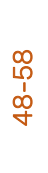 & 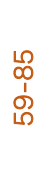 & $\stackrel{0}{0}$ & 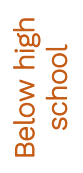 & 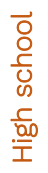 & $\begin{array}{l}\frac{0}{0} \\
\frac{\pi}{3} \\
\frac{\pi}{0} \\
\frac{\pi}{0}\end{array}$ & $\begin{array}{l}\stackrel{n}{\frac{0}{0}} \\
\frac{0}{0} \\
\frac{0}{\omega}\end{array}$ & 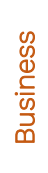 & 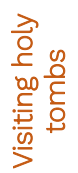 & 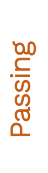 & 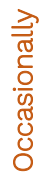 & 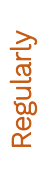 \\
\hline $\begin{array}{l}\text { Percentage of } \\
\text { visitors } \\
\text { (Mashruteh) }\end{array}$ & 24 & 76 & 25 & 25 & 25 & 25 & 3 & 31 & 51 & 15 & 30 & 18 & 5 & 47 & 44 & 56 \\
\hline $\begin{array}{l}\text { Percentage of } \\
\text { visitors } \\
\text { (Saheb-ol- } \\
\text { Amr) }\end{array}$ & 14 & 86 & 25 & 25 & 25 & 25 & 3 & 34 & 41 & 22 & 12 & 4 & NA & 84 & 47 & 56 \\
\hline
\end{tabular}

Source. Prepared by the authors.

ACE, 16 (4.7) CC BY-ND 3.0 ES | UPC Barcelona, España | The Impact of Changes in Environmental Meanings on 


\subsection{Data Collection Procedures}

A self-reported questionnaire was used to collect visiting users' perceptions and test Figure 2.

Based on the data in Table 2 and the study by Gifford (2011), interviews and questionnaires are the best options for evaluating the effectiveness of self-report methods regarding studying the perceptions and meanings of the environment. However, the questionnaire is the best tool for research goals and questions since the nature of the present work is not exploratory. This questionnaire is organized into three sections.

The first part includes demographic items on age, gender, and educational background, the purpose of visit, and frequency of visit. The second part contains items that measure visiting users' current perceptions of the environment on a Likert-type scale. In this section of the questionnaire, respondents are asked four questions corresponding to the four levels of perception.

The use of the Likert-type spectrum was employed in the development of the questionnaire because it allows grading the audiences' assessment of changes in their perceptions and the meanings they attribute to the environment. The five-point type of this scale is also more relevant to the type of questions and research objectives and prevents the excessive entry of the required data into the research.

The third part is related to changes in environmental meanings because of the infill architecture. It includes three items on changes at the sub-level of visual meaning (i.e., physical, and functional dimensions), two items on alterations at the sub-level of prescriptive meaning (functional dimension), and three items on changes at the sub-level of affective-judgmental meaning (i.e., historical, cultural, and social dimensions).

\subsection{Data Analysis}

The theoretical model of the study was developed based on the theoretical foundations and then analyzed using factor analysis.

In this method of data analysis, research variables are categorized so that they are limited to several factors, and the correlation between factors and variables can be examined by equations. The degree of this correlation shows the effect and variability of variables on/from each other. One of the important advantages of this method is the assumption that all variables are interdependent, which is highly helpful in such studies with a subjective nature.

Then, the relationship between the research variables (i.e., user perceptions and environmental meanings) and the extent of their impact on one another were investigated through logical argumentation.

Such a method of dealing with the research problem (using qualitative and quantitative methods), far from reducing the concepts of research to numbers, allows using mathematical arguments, which hinder the expression of personal perceptions due to their nature, and keeps the research in debatable and scientific scopes from this perspective.

ACE, 16 (47) CC BY-ND 3.0 ES | UPC Barcelona, España | The Impact of Changes in Environmental Meanings on Users' Perceptions. DOI: http://dx.doi.org/10.5821/ace.16.47.9638 


\subsection{Validity and Reliability}

According to experts' points of view, the developed questionnaire can evaluate the intended criteria of the research and the phrases are appropriate in terms of clarity, comprehensibility, and language type.

Next, KMO and Bartlett's test of sphericity were used to analyze the reliability of the load factor analysis. It yielded the coefficients of 0.642 and 0.722 for Mashruteh and Saheb-ol-Amr Complexes, respectively, which allowed for factor analysis since it was greater than 0.6. Additionally, Cronbach's alpha was used to confirm the reliability of the questionnaire. Accordingly, 30 questionnaires on user perceptions and changes in environmental meanings were completed in each sample by means of a pre-test, and Cronbach's alpha coefficients were calculated for each complex. To achieve optimal reliability, two items related to the sub-level of referential meaning were removed from the questionnaire. Then, the Cronbach's alpha coefficients of 0.73 and 0.74 were obtained for Mashruteh and Saheb-ol-Amr Complexes, respectively. After collecting the data for the entire sample population, the questionnaire yielded the reliability coefficients of 0.70 and 0.80 for Mashruteh and Saheb-ol-Amr complexes, respectively.

\section{Findings}

\subsection{Visiting Users' Evaluations of the Levels of Perceptions and Changes in Environmental Meanings}

Based on the collected data from the visitors' self-reported levels of perceptions and changes in environmental meanings in Mashruteh Complex because of the infill architecture, the factor loadings of measurement scales were in the range of 0.87-1.00, 0.71-0.77, and 0.41-0.91 for prescriptive meaning, affective-judgmental meaning, and perception levels, respectively. The data analysis for changes in environmental meanings showed that changes at the level of visual meaning had no impact on visiting users' perceptions because of a factor loading below 0.3. Conversely, changes in prescriptive (=1.00) and affective-judgmental (=0.61) meanings influenced the visiting users' perceptions of the infill architecture. Therefore, changes at the level of reactive meaning because of the infill architecture affected four levels of perception. Moreover, the analysis of changes in environmental meanings demonstrated that changes in use pattern associations and the organization of activities had the highest impact on users' perceptions in the order of importance at the level of prescriptive meaning. In addition, alterations in the implementation of religious and cultural events, as well as the moral and cultural values of the historic context had the highest effect on users' perceptions in the order of importance at the level of affective-reactive meaning. These findings do not account for the effects of intervening variables (Table 4).

The collected data from the users' assessments of the levels of perception and changes in environmental meanings in Sahob-ol-Amr Complex represented that factor loadings were within the range of 0.70-0.97, 0.81-0.93, 0.82-1.00, 0.73-0.82, and 0.36-0.62 for visual, prescriptive, affectivejudgmental, and reactive meaning, along with the levels of perception, respectively. The obtained data suggested that the level of affective perception should be eliminated for a factor loading below 0.3. Therefore, changes in the level of reactive meaning, particularly in affective-judgmental meaning, because of the infill architecture affected the three levels of perception. The analysis of changes in the levels of perception revealed that changes in the overall atmosphere, formal details, and the appearance of the historic context had the highest impact in the order of importance at the level of visual meaning. Further, changes in the organization of activities and use pattern associations had the highest impact in the order of importance.

ACE, 16 (47) CC BY-ND 3.0 ES | UPC Barcelona, España | The Impact of Changes in Environmental Meanings on

Users' Perceptions. DOI: http://dx.doi.org/10.5821/ace.16.47.9638 
After all, changes in the implementation of religious and cultural events, as well as the moral and cultural values had the highest impact in the order of importance at the level of affective-reactive meaning. Therefore, visiting users' levels of perception were mostly affected by changes in affectivejudgmental meaning and the historic context's features at the level of reactive meaning (Table 4).

Tabla 4. Factor Loadings and Significance Levels Relating to the Levels of Perception and Changes in Environmental Meanings

\begin{tabular}{|c|c|c|c|c|c|c|c|}
\hline $\begin{array}{l}\text { Infill } \\
\text { construction }\end{array}$ & Group & \multicolumn{3}{|c|}{ Measurement Scale } & \multicolumn{2}{|c|}{ Factor Loading } & Symbol \\
\hline \multirow{9}{*}{ 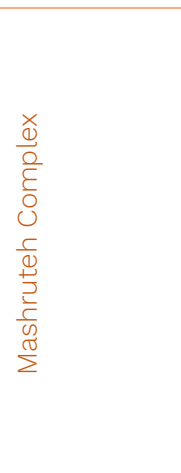 } & \multirow{4}{*}{ 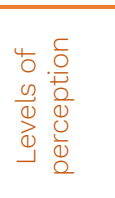 } & \multicolumn{3}{|c|}{ Cognitive level } & \multicolumn{2}{|c|}{0.41} & $\mathrm{P} 1$ \\
\hline & & \multicolumn{3}{|c|}{ Affective level } & \multicolumn{2}{|c|}{0.48} & P2 \\
\hline & & \multicolumn{3}{|c|}{ Interpretive level } & \multicolumn{2}{|c|}{0.82} & P3 \\
\hline & & \multicolumn{3}{|c|}{ Evaluative level } & \multicolumn{2}{|c|}{0.91} & P4 \\
\hline & \multirow{5}{*}{ 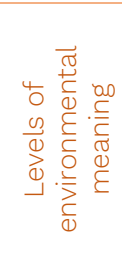 } & \multirow{5}{*}{ 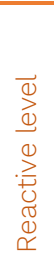 } & \multirow[t]{2}{*}{ Prescriptive } & Use pattern associations & \multirow{2}{*}{$\stackrel{\circ}{\circ}$} & 1.00 & M4 \\
\hline & & & & $\begin{array}{l}\text { Organization of use } \\
\text { patterns }\end{array}$ & & 0.87 & M5 \\
\hline & & & \multirow{3}{*}{$\begin{array}{l}\text { Affective- } \\
\text { judgmental }\end{array}$} & Religious and cultural & \multirow{3}{*}{$\bar{\sigma}$} & 0.71 & M6 \\
\hline & & & & events & & \multirow[t]{2}{*}{0.77} & \multirow[t]{2}{*}{ M8 } \\
\hline & & & & Moral and cultural values & & & \\
\hline \multirow{5}{*}{ 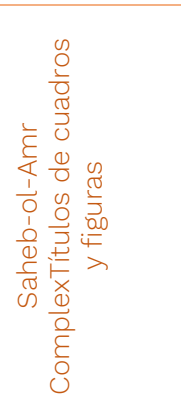 } & \multirow{3}{*}{ 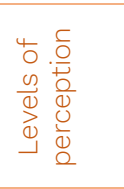 } & \multicolumn{2}{|c|}{ Cognitive level } & & \multicolumn{2}{|c|}{0.62} & $\mathrm{P} 1$ \\
\hline & & \multicolumn{3}{|c|}{ Interpretive level } & \multicolumn{2}{|c|}{0.36} & P3 \\
\hline & & \multicolumn{3}{|c|}{ Evaluative level } & \multicolumn{2}{|c|}{0.55} & P4 \\
\hline & \multirow{2}{*}{ 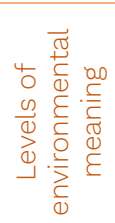 } & \multirow{2}{*}{$\begin{array}{l}\overrightarrow{\widetilde{D}} \\
\frac{\vec{d}}{\vec{\sigma}} \\
\stackrel{0}{\overrightarrow{0}} \\
\stackrel{0}{>}\end{array}$} & \multicolumn{2}{|c|}{ Overall atmosphere } & \multirow{2}{*}{ 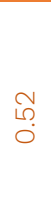 } & 0.97 & M1 \\
\hline & & & \multicolumn{2}{|c|}{ Formal details } & & 0.96 & M2 \\
\hline
\end{tabular}

Note. $p<0.001$

Source. Prepared by the authors.

\subsection{Investigating the Effects of Individual Factors on the Visiting Users' Levels of Perception}

A summary of how individual factors can influence the visiting users' perceptions of the infill architecture is presented in Tables 5 and 6 . Table 5 provides the effects of moderating variables with a sequential nature through correlation coefficients. As shown, there is a slight insignificant relationship between age and the quality of perception. There is also a direct relationship between age and changes in environmental meaning.

This implies that the audience experiences fewer changes in the meanings of the historical context of the market because of infill by decreasing age.

The relationship between education and the quality of perception is inverse and insignificant whereas the one between education and changes in the environmental meaning is unstable. Based on the findings, the relationship between the frequency of visits, the quality of perception, and changes in the environmental meaning is inverse and insignificant in Saheb-ol-Amr Complex while it is direct in Mashruteh Complex. 
Tabla 5. Correlation Coefficients Between Individual factors and Perceptions of Environment/Environmental Meanings (Mashruteh and Saheb-ol-Amr Complexes)

\begin{tabular}{|c|c|c|c|c|c|c|c|c|}
\hline \multicolumn{2}{|c|}{$\begin{array}{l}\text { Individual } \\
\text { Factors }\end{array}$} & \multirow{2}{*}{$\begin{array}{l}\text { Coefficients } \\
\text { Correlation }\end{array}$} & \multirow{2}{*}{$\begin{array}{l}\text { Levels of } \\
\text { Perception } \\
0.037\end{array}$} & \multirow{2}{*}{$\begin{array}{l}\text { Changes } \\
\text { in } \\
\text { Environm } \\
\text { ental } \\
\text { Meanings } \\
0.202^{\star \star}\end{array}$} & \multirow{2}{*}{$\begin{array}{l}\text { Affective- } \\
\text { judgemen } \\
\text { tal } \\
\text { Meaning } \\
0.303^{\star \star}\end{array}$} & \multirow{2}{*}{$\begin{array}{l}\text { Perspective } \\
\text { Meaning } \\
0.169^{\star}\end{array}$} & \multirow{2}{*}{$\begin{array}{c}\text { Reactive } \\
\text { Meaning } \\
0.281^{\star \star}\end{array}$} & \multirow{2}{*}{$\begin{array}{l}\text { Visual } \\
\text { Meaning } \\
0.037\end{array}$} \\
\hline & $\begin{array}{l}\text { Mashrute } \\
\text { h }\end{array}$ & & & & & & & \\
\hline & Complex & Significance & 0.623 & 0.007 & $0.001>$ & 0.025 & $0.001>$ & 0.622 \\
\hline \multirow{2}{*}{$\begin{array}{l}1 \\
20 \\
\leftarrow\end{array}$} & \multirow{2}{*}{$\begin{array}{l}\text { Saheb-ol- } \\
\text { Amr } \\
\text { Complex }\end{array}$} & Correlation & -0.011 & 0.102 & -0.057 & -0.016 & -0.064 & $0.203^{* \star}$ \\
\hline & & Significance & 0.888 & 0.178 & 0.454 & 0.834 & 0.403 & 0.007 \\
\hline \multirow{4}{*}{ 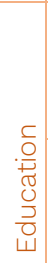 } & \multirow{2}{*}{$\begin{array}{l}\text { Mashrute } \\
\text { h } \\
\text { Complex }\end{array}$} & Correlation & $-0.182^{*}$ & $-0.258^{\star \star}$ & $0.303^{\star * \star}$ & $0.231^{\star \star}$ & $-0.303^{\star \star}$ & -0.078 \\
\hline & & Significance & 0.016 & 0.001 & $0.001>$ & 0.002 & 0.001 & 0.301 \\
\hline & \multirow{2}{*}{$\begin{array}{l}\text { Saheb-ol- } \\
\text { Amr } \\
\text { Complex }\end{array}$} & Correlation & -0.011 & 0.076 & 0.127 & 0.018 & 0.115 & -0.147 \\
\hline & & Significance & 0.883 & 0.317 & 0.096 & 0.815 & 0.317 & 0.053 \\
\hline \multirow{5}{*}{ 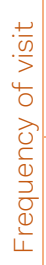 } & \multirow{3}{*}{$\begin{array}{l}\text { Mashrute } \\
\text { h } \\
\text { Complex }\end{array}$} & Correlation & $0.177^{\star}$ & 0.028 & $0.279^{\star *}$ & 0.014 & $0.177^{*}$ & $-0.186^{*}$ \\
\hline & & & & & & & & \\
\hline & & Significance & 0.019 & 0.710 & $0.001>$ & 0.085 & 0.019 & 0.014 \\
\hline & \multirow{2}{*}{$\begin{array}{l}\text { Saheb-ol- } \\
\text { Amr } \\
\text { Complex }\end{array}$} & Correlation & -0.128 & -0.137 & 0.055 & -0.024 & 0.052 & $-0.193^{*}$ \\
\hline & & Significance & 0.092 & 0.072 & 0.469 & 0.754 & 0.493 & 0.011 \\
\hline
\end{tabular}

Source. Prepared by the authors.

Table 6 presents the effects of moderating variables with a nominal nature on the visiting users' assessments of changes in environmental meanings and the levels of perception based on a Likerttype scale and the coefficients of significance. As shown, gender and the purpose of visits are irrelevant to the quality of perception and changes in meaning.

\section{Discussion}

The statistical analyses of the data for Mashruteh Complex showed that visiting users evaluated their levels of environmental perception as good. In this assessment, changes at the sub-level of visual meaning, which is limited to expository meanings, had no impact on the users' levels of perception. The greatest effect on these sub-levels was related to changes in environmental meanings at the level of prescriptive meaning. At this level, changes in use pattern associations and in the organization of activities demonstrated the highest impact on visiting users' perceptions in the order of importance. It seems that Mashruteh Complex, due to the creation of parking space facilities, paved the way for visiting users to benefit from Mashruteh Complex and the Historic Bazaar Context in general. This has also boosted the trade and improved the main performance of the Historic Bazaar context. However, the Historic Bazaar has a lower capacity for trading or transferring large goods because of narrower paths and the limited space of the stores.

ACE, 16 (4.7) CC BY-ND 3.0 ES | UPC Barcelona, España | The Impact of Changes in Environmental Meanings on Users' Perceptions. DOI: http://dx.doi.org/10.5821/ace.16.47.9638 
Tabla 61 Visiting Users' Assessments of the Levels of Perception and Changes in Environmental Meanings Based on Individual Factors

\begin{tabular}{|c|c|c|c|c|c|c|c|c|}
\hline \multicolumn{2}{|c|}{$\begin{array}{l}\text { Individual } \\
\text { Factors }\end{array}$} & \multirow{2}{*}{$\begin{array}{l}\text { Coefficients } \\
\text { Female }\end{array}$} & \multirow{2}{*}{$\begin{array}{l}\text { Levels of } \\
\text { Perception } \\
3.79\end{array}$} & \multirow{2}{*}{$\begin{array}{l}\text { Changes in } \\
\text { Environm. } \\
\text { Meanings } \\
3.61\end{array}$} & \multirow{2}{*}{$\begin{array}{l}\text { Affective- } \\
\text { Judgmental } \\
\text { Meaning } \\
2.99\end{array}$} & \multirow{2}{*}{$\begin{array}{l}\text { Prescriptive } \\
\text { Meaning } \\
4\end{array}$} & \multirow{2}{*}{$\begin{array}{c}\text { Reactive } \\
\text { Meaning } \\
3.39\end{array}$} & \multirow{2}{*}{$\begin{array}{l}\text { Visual } \\
\text { Meaning } \\
3.61\end{array}$} \\
\hline \multirow{6}{*}{ 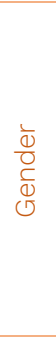 } & \multirow{3}{*}{ 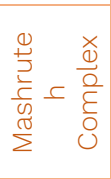 } & & & & & & & \\
\hline & & Male & 3.71 & 3.46 & 3.34 & 4.12 & 3.65 & 3.15 \\
\hline & & $\begin{array}{l}\text { Correlation } \\
\text { coefficient }\end{array}$ & 0.633 & 0.156 & 0.003 & 0.814 & 0.092 & $<0.001$ \\
\hline & \multirow{3}{*}{ 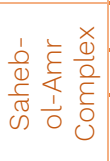 } & Female & 2.60 & 2.49 & 2.04 & 2 & 2.04 & 3.24 \\
\hline & & Male & 2.54 & 2.32 & 2.21 & 2.12 & 2.21 & 2.32 \\
\hline & & $\begin{array}{l}\text { Correlation } \\
\text { coefficient }\end{array}$ & 0.349 & 0.015 & 0.009 & 0.060 & 0.006 & $<0.001$ \\
\hline \multirow{9}{*}{ 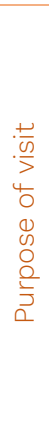 } & \multirow{5}{*}{ 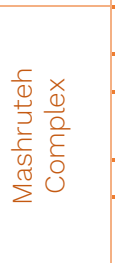 } & Shopping & 3.66 & 3.55 & 3.01 & 4 & 3.40 & 3.80 \\
\hline & & Business & 3.78 & 3.45 & 3.51 & 3.96 & 3.69 & 3.04 \\
\hline & & $\begin{array}{l}\text { Visiting holy } \\
\text { tombs }\end{array}$ & 3.44 & 3.51 & 3.40 & 4.55 & 3.86 & 2.92 \\
\hline & & Passing & 3.79 & 3.49 & 3.29 & 4.14 & 3.63 & 3.26 \\
\hline & & $\begin{array}{l}\text { Correlation } \\
\text { coefficient }\end{array}$ & 0.476 & 0.878 & 0.005 & 0.412 & 0.289 & $<0.001$ \\
\hline & \multirow{4}{*}{ 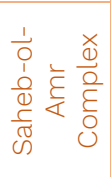 } & Shopping & 2.54 & 2.41 & 2.31 & 2.14 & 2.24 & 2.68 \\
\hline & & Business & 2.57 & 2.19 & 2.19 & 1.85 & 2.05 & 2.42 \\
\hline & & Passing & 2.53 & 2.8 & 2.23 & 2.10 & 2.18 & 2.62 \\
\hline & & $\begin{array}{l}\text { Correlation } \\
\text { coefficient }\end{array}$ & 0.970 & 0.737 & 0.630 & 0.141 & 0.652 & 0.876 \\
\hline
\end{tabular}

Note. Assessments were based on a five-point Likert-type scale ( $1=$ Very bad, 2 = Bad, $3=$ Normal, $4=$ Good, and 5 = Very good)

Source. Prepared by the authors.

Therefore, Mashruteh Complex can compensate for this shortage by supporting the historic context to provide contemporary needs, which will, in turn, improve the organization and integration of business uses in old and new contexts. Mashruteh Complex, as a case of infill architecture, helps improve traffic congestion and transportation problems, enhance combined use patterns, achieve self-sufficiency in urban areas, meet human needs, and provide public services for citizens, all of which affect and improve the aspects of the urban space in general. In addition, changes at the sublevel of affective-judgmental meaning, after prescriptive meaning, highly affected the visiting users' levels of perception, which is most probably rooted in the fact that the socio-cultural stratum of visitors to the historic context did not change significantly after the construction of Mashruteh Complex. Even, some of the changes made to the historic context were not constant and this cannot possibly be expected to cause significant changes. Accordingly, the small extent of changes in visiting users caused the Historic Bazaar context to continue to enjoy its centrality for religious and cultural events and sustain its moral values.

However, a factor loading of less than 0.3 for the level of reactive meaning, as a combination of prescriptive and affective-judgmental sub-levels, pointed to the fact that this level had no impact on the users' levels of perception. The findings of the structural equation modelling with IBM SPSS Statistics revealed that the best path for the impact of changes in environmental meanings on the users' levels of perception was that of the impact of changes at the reactive level on cognitive, affective, interpretive, and evaluative perception levels (Figure 11). Although Marotta et al., (2017) suggested that environmental performance and changes in performance-related environmental meanings are not the most effective factors in the users' perceptions. the findings of the present study indicated that the opposite - that is, the component of changes in environmental meanings, with the highest factor loading ( $=1$ ), has the strongest impact on user perceptions. 
The statistical analyses of the data also showed a direct and significant relationship between the users' levels of perception and changes in environmental meanings. In other words, better evaluations of changes in environmental meanings were associated with better evaluations of the levels of perception. In these evaluations, age, education, and the frequency of visits were also effective factors, which is consistent with the findings of Kang and Zhang (2010). However, gender and the purpose of the visit were considered ineffective.

\section{Figure 11. Structural Equation Modelling of the Levels of the Environmental Perception in Mashruteh Complex (Software output)}

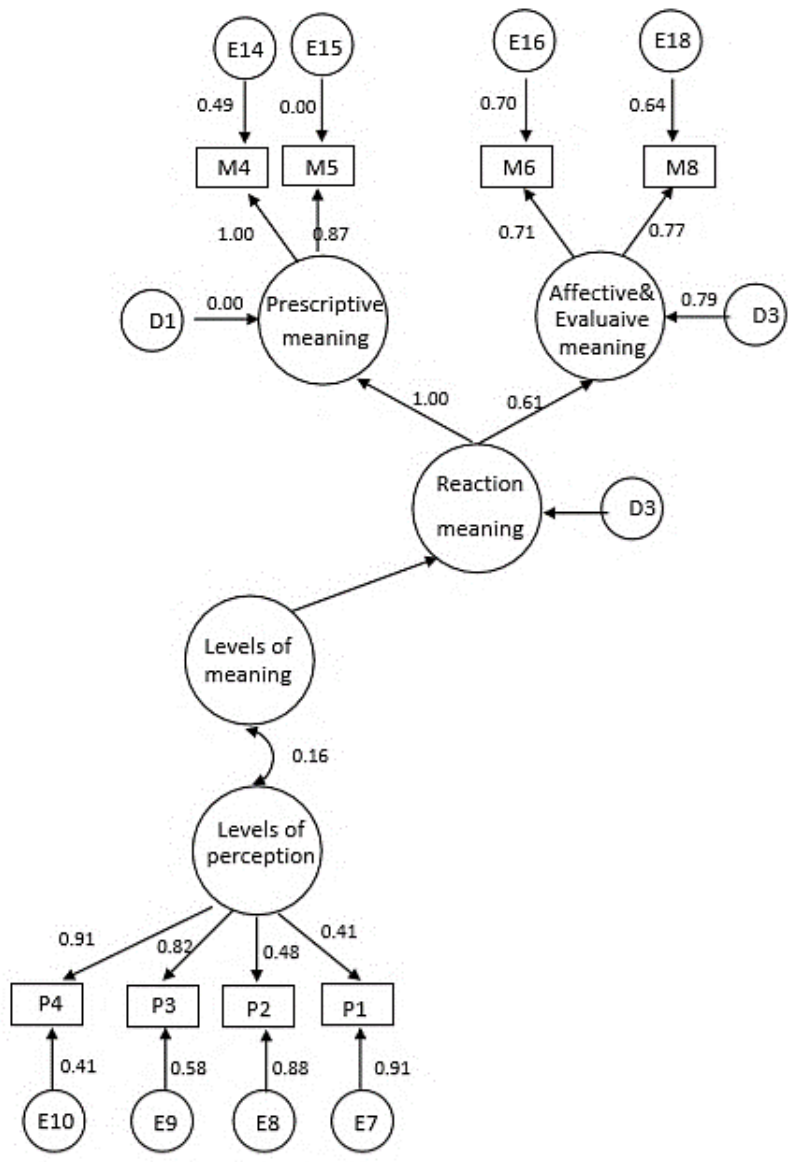

Source. Prepared by the authors.

The findings in relation to Saheb-ol-Amr Complex demonstrated that visiting users' self-reported perceptions were normal at the cognitive level but bad at the affective-interpretive level. Based on this assessment, changes at the level of reactive meanings, especially the sub-level of affectivejudgmental meaning, had the greatest impact. Changes in environmental meanings, - because of changes in the historic features of the Historic Bazaar; religious and cultural events, and, ethical and cultural values, - had the highest contribution in this assessment. It seems that the participants' normal evaluation of the cognitive and evaluative levels of perception has resulted from their assessment of cultural, social, and historical characteristics as undesirable, which led to their unwillingness to use the context for holding events. Furthermore, the events that occurred during the demolition of the old context caused marketers and business owners to avoid purchasing commercial spaces because they believed that most of the old stores were destroyed without the consent of the owners.

ACE, 16 (4.7) CC BY-ND 3.0 ES | UPC Barcelona, España | The Impact of Changes in Environmental Meanings on 
This led to the failure of the new infill structure, which was added to the Historic Bazaar, to function properly. After this sub-level, prescriptive meanings had the greatest impact on the visiting users' levels of perception. At this sub-level, the greatest impact on cognitive, interpretive, and evaluative levels of perception was visible in the organization of activities and use pattern associations, in the order of importance. Additionally, due to the nature of Saheb-ol-Amr Complex, the participants reported that changes in environmental meanings associated with functions and use patterns were weak.

Among the factors, affecting this evaluation included could be the policies of related organizations for the sale of commercial spaces; the owners' lack of consent for demolitions before the infill architecture, inappropriate circulation systems, and ineffective parking spaces alongside the margins of Chaykenar Street. After changes at the level of reactive meaning, changes at the level of visual meaning had the greatest impact on the visiting users' levels of perception, followed by changes at the level of visual meaning. At this level of meaning, the overall atmosphere of the architecture, formal details, and the appearance of the historic context had the greatest impact, in the order of importance. Most users evaluated these meanings as bad. The poor performance of the complex seems to be the main reason in this regard. On the one hand, the lack of proper use has caused the deserted body of the complex to undergo damages over time. On the other hand, the fact that the complex is rarely visited and some of its parts are out of sight, especially the courtyards, has made it prone to criminal activities and accelerated its process of exhaustion. These assessments of changes in environmental meanings because of the construction of Saheb-ol-Amr Complex had an impact on cognitive, interpretive, and evaluative levels of perception. Insofar as visiting users evaluated these characteristics as undesirable, the affected levels of perception were also evaluated as poor (Figure 12).

Figure 12. Structural Equation Modelling of the Levels of the Environmental Perception in Saheb-ol-Amr Complex (Software output)

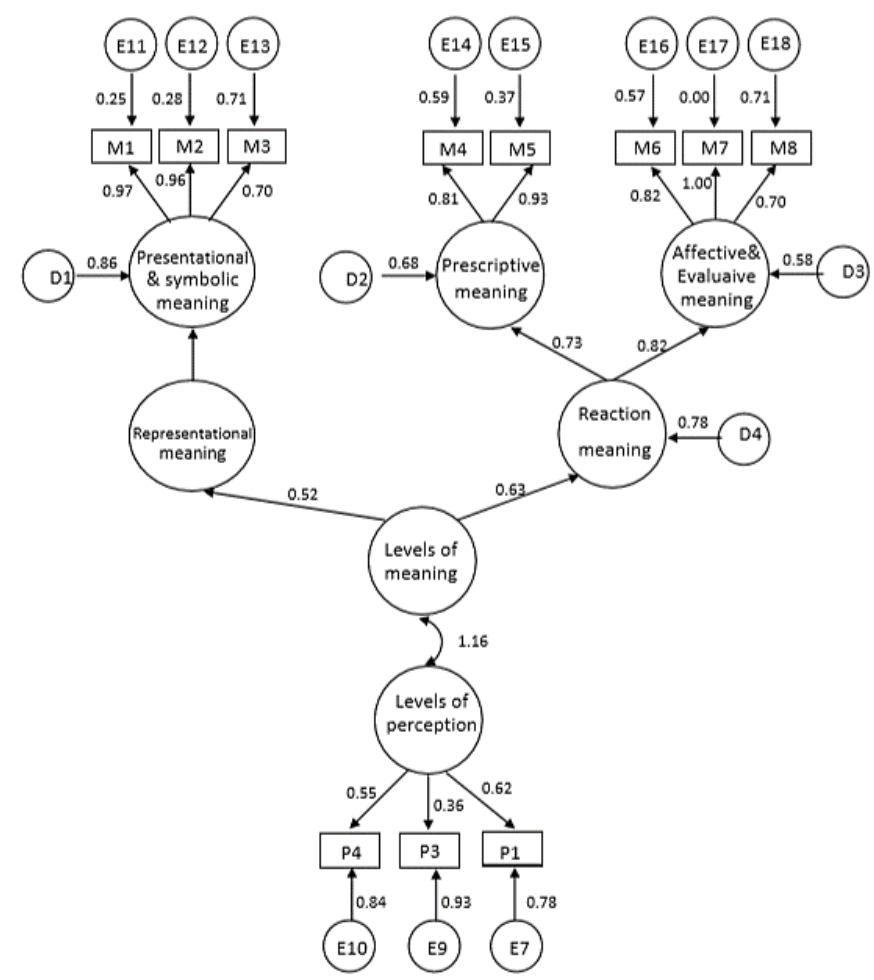

Source. Prepared by the authors.

ACE, 16 (4.7) CC BY-ND 3.0 ES | UPC Barcelona, España | The Impact of Changes in Environmental Meanings on 
The present findings contradict the findings of Marotta et al., (2017), suggesting that environmental performance and changes in performance-related environmental meanings are not the most effective factors in the users' perceptions of a given environment. Our study indicates the opposite, that is, the component of changes in environmental meanings, with the highest factor loading (=1), has the strongest impact on user perceptions. Based on Our statistical analyses of the data in this section, also show that there was a direct and significant relationship between the users' levels of perception and changes in environmental meanings. In these assessments, none of the individual factors was effective, which does not match to the findings of Kang and Zhang (2010).

These data show that in both complexes, changes at the reactive level, including prescriptive and affective-judgmental meaning, had an impact on users' perceptions in both complexes. Although, the difference that in Mashruteh Complex, all the four levels of perception were affected in Mashruteh Complex, but in Saheb-ol-Amr Complex, only three were affected, namely, cognition, interpretation, and evaluation levels were affected in Saheb-ol-Amr Complex. This indicates the importance of meanings as extracted from functional, historical, and socio-cultural components. Changes at the level of visual meaning, which relies on physical components, affected the visiting users' levels of perception depending on the status of the provision of services by the body of infill buildings, policies, and physical conditions. For instance, changes at this level of meaning affected the users' perceptions of Mashruteh Complex but failed to affect the users' perceptions of Saheb-ol-Amr Complex.

\section{Conclusion}

This study focused on the effect of infill buildings on the context of the Historic Bazaar of Tabriz by evaluating the effect of changes in environmental meanings, because of the infill architecture, on users' perceptions. The investigation of this issue is important because it is impossible to study architecture and city categories only from their physical and tangible aspects while ignoring their mental aspects such as perceptions and meanings, especially when confronted with the historical context and additions of contemporary architecture. This issue has been so far overlooked in this type of architecture. On the other hand, the evaluation meaning in relation to perceptions has so far been based on semiotic studies and theories in architecture and urban studies. Recently, a limited body of research has proposed and adopted a new approach in such studies. Semantics, as a branch of linguistics that exclusively deals with the study of meaning, can open a new window in the investigation of meanings and perceptions in architectural and urban studies. To this end, in this study, the recent approach was used to design and follow the study of meaning with respect to the perception of the environment from the perspective of semantic theories.

The findings of this study in relation to Mashruteh and Saheb-ol-Amr Complexes showed that changes in the physical and non-physical components of the Historic Bazaar resulted in alterations in environmental meanings. The quality of these changes also affected the visiting users' perceptions of infill buildings via a direct and significant relationship. A comparative analysis of the findings regarding the above-mentioned complexes revealed that changes at the level of reactive meaning, including the prescriptive and affective-judgmental sub-levels, affected the visiting users' perceptions of both infill buildings.

ACE, 16 (4.7) CC BY-ND 3.0 ES | UPC Barcelona, España | The Impact of Changes in Environmental Meanings on Users' Perceptions. DOI: http://dx.doi.org/10.5821/ace.16.47.9638 
Based on the physical and non-physical characteristics of the infill architecture, the opportunities that it provides, and the threats that it poses in addition to its location in the historic context. The design and construction process, and other factors, the proposed model in Figure 1 is not a fixed model, but rather, it is prone to a change depending on the situation. This change highlights the importance of some factors in altering the meanings and the users' perceptions of the infill architecture in the historic context and reveals the less important position of other factors.

Such conclusions regarding the studied cases can provide information for the planner and law enactment organizations, based on which and considering the development of guidelines, the subject of the design approach in infill buildings in the historical context can be considered more consciously. Additionally, the presented issues for correcting the problems of these two infill buildings (depending on the issue that in which components changes have demonstrated negative feedback from the audience' perceptions) and designing future infill buildings in the Tabriz market can also be helpful. In this regard, developing such a model and testing it in the environment lead to findings that provide a good reference for presenting solutions to the redesigning of these two infill buildings aiming at improving the quality of visiting users' perceptions and changes in environmental meanings. This is possible by increasing the number of case studies and further focusing on intervening variables, especially those that are related to culture.

\section{Authorship}

This article is part of Ilghar Ardabilchi's master's thesis titled "Examining the Levels of People's Perception of Infill Architecture in the Historic Contexts of Tabriz City (Case Study: Infill Architecture between the Historic Bazaar of Tabriz and the Margins of Chaykenar)" under the supervision of Dr. Minou at the Faculty of Architecture and Urbanism, Tabriz Islamic Art University.

\section{Bibliography}

Blaikie, N. (2010). Designing Social Research. Second edition. Polity Press.

Carmona, M.; Heath, T.; Taner, O. y Tiesdell, S. (2003). Public places-urban spaces. Architectural Press.

Clark, A. y Toribio, J. (2011). Artificial intelligence and cognitive science: language and meaning in cognitive science. Routledge.

Fischoff, B. (2015). Environmental cognition, perception, and attitudes. International Encyclopedia of the Social \& Behavioral Sciences, 7, 706-712. DOI: 10.1016/B978-0-08-097086-8.91012-2

Gharebaglou Minou; Nejad Ebrahimi Ahad; Ardabilchi Ilgar (2019). Infill Architecture: An Interdisciplinary Approach to the Design of Historic Context; Case Study: Mashruteh Complex in the Historic Bazaar of Tabriz, Iran. Bagh-e Nazar, 76, 57-68. DOI: 10.22034/bagh.2019.142666.3713.

Garica Mira, R. y Real Deus, E. (2005). Environmental perception and cognitive maps. International journal of psychology, 40 (1), 1-2. DOI: 10.1080/00207590444000069.

Geeraerts, D. (2010). Theories of Lexical Semantics. Oxford University Press.

Gifford, R. (2016). Research method for environmental psychology. Willey Publishers.

ACE, 16 (4.7) CC BY-ND 3.0 ES | UPC Barcelona, España | The Impact of Changes in Environmental Meanings on 
Gifford, R.; Steg, L. y P. Reser, J. (2011). Environmental Psychology in IAAP handbook of applied psychology. Editor(s): Paul R. Martin, Fanny M. Cheung BA,, Michael C. Knowles MCom (Qld), Michael Kyrios, J. Bruce Overmier, José M. Prieto UK, Oxford: Wiley-Blackwell. DOI: 10.1002/9781444395150.ch18

Gordon, I. (2005). Theories of Visual Perception. Third edition. USA: NY: Psychology Press. DOI: $10.4324 / 9780203502259$

Gorski, E. (2009). Regulating new construction in historical contexts. USA, Washington DC: National trust for historic preservation.

Haughey, R. (2001). Urban infill housing: Myth and fact. Urban Land Institute.

Kellerhals, U. y Schaeppi, w. (2007). The semantics of architecture. MRC marketing research \& consulting $A G, 31,1-12$.

Lang, J. (1987). Creating Architectural Theory: The Role of the Behavioral Sciences in Environmental Design. USA: Van Nostrand Reinhold Company.

Lappin, S.; Fox, C. (2015). The handbook of contemporary semantic theory. UK, West Sussex: King's College. DOI: 10.1002/9781118882139

Lappin, S. y Fox, C. (2015). Contemporary Semantic Theory. second edition. Wiley Blackwell.

Lyons, J. (1995). Linguistic Semantics: An Introduction. Cambridge University Press.

Marotta, A.; Spallone, R.; Lo Turco, M.; Zich, U.; Vitali, M.; Marchis, E. y Pavignano, M. (2017). Visual Images and Language in Architecture: Signifier Semiotics and Meaning Semiotics. Proceedings, 1:9, 964-981. DOI: 10.3390/proceedings1090964

Nasar, J. (1990). The Evaluative Image of the City. Journal of the American Planning Association, 56(1), 41-53. DOI: $10.1080 / 01944369008975742$

Ogden, C.; Richards, I. A. y Malinowski, B. (2013). The Meaning of Meaning: A Study of the Influence of Language upon Thought and of the Science of Symbolism. Rutledge.

Penton, D. y Bird, S. (2004). Representing and Rendering Linguistic Paradigms. Proceedings of the Australasian Language Technology Workshop 2004 (123-130).

Rookes, P. y Willson, J. (2000). Perception Theory, development, and organization. Routledge.

Sajadzadeh, H., Eris, B. (2017). The study of meaning production in urban spaces based on the structuration theory case study: Tabriz Bazaar. Human Geography Research, 49(2), 273-287. DOI: 10.22059/jhgr.2017.55475

Sajadzadeh, H. y Piribabai, M. (2012). The Process of Signification in Urban Spaces [Original in Persian]. Armanshahr Journal, 9, 177-186.

Sotoudeh, H. \& Wan Abdullah, W. (2013). Contextual Preferences of Experts and Residents: Issue of Replication and Differentiation for New Infill Design in Urban Historical Context. World Applied Sciences Journal, 21, 1276-1281. DOI: 10.5829/idosi.wasj.2013.21.9.160

ACE, 16 (4.7) CC BY-ND 3.0 ES | UPC Barcelona, España | The Impact of Changes in Environmental Meanings on 
Taurens, J. (2008). 'Meaning' and 'Context' in the Language of Architecture, 71-82. https://docplayer.net/10722087-Meaning-and-context-in-the-language-of-architecture-.html

United state environmental protection agency. (2015). Attracting infill development in distressed communities: 30 strategies. EPA.

Williams, C. (2014). Integrating Infill Planning in California's General Plans: A Policy Roadmap Based on Best-Practice Communities. University of California Berkeley School of Law.

Wolf, B. (2005). Brunswik's original lens model. University of Landau. https://www.albany.edu/cpr/brunswik/notes/WolfOriginalLens2005.pdf

Yazdanfar, A.; Heidari, A. y; Aghajari, N. (2014). Comparison of architects' and non-architects' perception of place. Procedia - Social and Behavioral Sciences, 170 (27), 690-699. DOI: 10.1016/j.sbspro.2015.01.071

Zhang, M. y Kang, J. (2010). Semantic differential analysis of the soundscape in urban open public spaces. Building and Environment, 45, 150-157. DOI: 10.1121/1.4779999 